\author{
B.R. Khassenov ${ }^{1, *}$, L.A. Nefedova ${ }^{2}$, A.S. Adilova ${ }^{1}$ \\ ${ }^{\prime}$ E.A. Buketov Karaganda University, Karaganda; \\ ${ }^{2}$ Chelyabinsk State University, Chelyabinsk; \\ (E-mail:boka_001kz@mail.ru,lan2@mail.ru,adilova2010@mail.ru)
}

\title{
Mythical and linguistic interpretation of the sign point inside the circle
}

\begin{abstract}
The article is devoted to the hypotheses of S. Qondybai about the archetype sign and sound, which are perceived as changes in Kazakh humanitarian science. S. Qondybai «The Head of Kazakh Mythology» during his short life has made great changes in Kazakh science. He connected several scientific paradigm and made many discoveries in the field of mythology and linguistics. Especially, his opinion of archetypal sounds should not remain out of the researchers' sight. Turcologist researchers define an archetypal sound at the beginning of a word through sounds that are found in records of written culture of the Ancient and Middle Turkish period. And also, consider the sound «j» is an archetype, comparing with modern Turkish languages and dialects. Some researchers disagree with this and consider the affricate «dzh» (дж) to be original. Modern researchers hold the view of affricates «tch» (ч) and «ts» (ц) — as former affricates in the languages of the Western and Eastern Hun. And the mythologist S. Qondybai developed his opinion of archetypal sounds in a completely different direction. He took into account the opinion of O. Suleimenov «the original sign — is the sign of the point inside the circle», all alphabetical signs begin with this sign. "At the same time, proved that this sign is connected not only with the Sun, but also showed a new example of reading. He called this sign «abak» (lattice) and marked this sound, a sign of $\mathrm{H}(\mathrm{Ng})$. He linked the name of this sign to the fact that mankind is born having made this sound. That is, in his opinion, the original sound $-\mathrm{H}(\mathrm{Ng})$. In this scientific article, the authors tried to give a complete description of these ideas, and to order an original understanding, reading of the symbol point inside the circle S. Qondybai.
\end{abstract}

Keywords: archetype sound, sign, sound, circle, point, essence, language sign, moon, sun.

\section{Introduction}

O. Suleimenov in his 1998 work «The Language of Writing», wrote in the introduction as follows: «I wrote this book and gradually became convinced that at first there was a sign and its oral description - a word. These were the emblems of God and His names» [1; 10]. In this study, he criticized F.de Saussure's view of the language sign as «the language sign is unfounded». In his opinion, the term of the word was confused with the term of the sign, the same prevented the development of linguistics. In linguistics, the Saussure's notion of «language sign - unfounded» was formed by the foundation of the study of the word. The emergence of this notion prevented the development of the most important channel of linguistics, etymologies. O. Suleimenov tells about the appearance of the word related to the figurative sign. The great teacher of human-

ity — is that Mother Nature itself formed the original sign or geometric figure. It's a circle $\square$. This sign was originally a symbol of the moon. «The moon became a deity in the southern latitudes. Taught a man to draw a circle, create a material idol - a disk of clay and stone. And to read everything round on earth: such is convenient to God.... Trying to draw the perfect circle, the priest creates a device that we use to this day. The circular in addition to the circle produced another not provided icon - a recess in the center from the support leg» $[1 ; 49]$. However, it was not depicted as a spot symbol on the moon that did not affect the meaning of the sign.

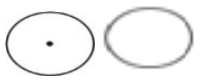

The name of the two signs, became common to all. The essence of the opinion of O. Suleimenov is the original sign, it is a circle, and the circle with a point inside, is the beginning of all alphabetical signs. Its original name cannot be restored. Ancient predictors called «moon» and «boon» due to the similarity of the symbol of the new moon with the horns of the bull. Because of the great caravan 's move to the North, the forecasters changed their minds in reference to the Moon, and began to worship the Sun. Starting from this period, the point inside the circle, was depicted as a symbol of death, the Moon 's chair. New examples of sign reading have emerged.

\footnotetext{
*Corresponding author's e-mail: boka_001kz@mail.ru
} 
The opinion of O. Suleimenov, that the sign of the point inside the circle is the most original, is reasonable. R. Genon in his work «Symbols of Sacred Science» wrote so about this symbol: «The center is, first of all, the beginning, the starting point of all things, the point of the root cause, without shape and size, is therefore indivisible, and therefore the only possible image of the originally Unified. From it, through its manifestation, happened everything else, just as the United produces all numbers, which, however, in no way affects its essence and does not change it.... The central point is the Principle, pure Genesis, but the space which it fills with its radiation and which exists only by virtue of this radiation («Let there be light», the Book of Genesis), without which it would be only «absence» and nothingness, it is the World in the sense of its undisturbed, the totality of all beings and all the states of the Essential, which form a universal manifestation. The simplest image of the idea we have formulated is the point in the center of the circle (Figure 1):

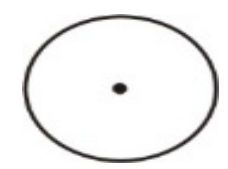

Figure 1. The point in the center of the circle

Point is a sign of Notion, circle is a symbol of Peace. It is impossible to record the temporary origin of this image, as it is often found on prehistoric-era subjects; There is no doubt that it is necessary to see a direct rise to the original tradition» [2]. Besides, according to R. Genon, the sign of the point inside the circle depicted not only the Sun. «The point in the Center of the Circle was also perceived, and from very ancient times, as an image of the Sun, because the latter and indeed, at the level of physical, there is the Center or» Heart of the World. «In this meaning, it has reached the present day as a generally accepted astrological or astronomical sign of the Sun. Maybe that is why most archaeologists everywhere they meet this symbol tend to give it meaning exclusively to «solar», although in reality it makes sense much more extensive and deep. They forget or do not know that in terms of ancient traditions and the sun is only a symbol, a symbol of the original «Center of the World» which the Divine Principle is». So, as Serikbol Qondybai said — the way O.Suleimenov depicted the point sign inside the circle as a symbol of the sun, is just one of the episodes of reading the sign.

S. Qondybai is the one who has formulated a new opinion about the sign of the point within the circle as a symbol not only of the Sun and Moon, but also of other objects. He came to this conclusion based on the ideas of O. Suleimenov: «First - the most original sign is the sign inside the circle, that is, the sign — lattice, second - all alphabetical signs begin with this sign and studying the evolution of the change of signs, it is possible to learn the original meaning of words». S. Qondybai gives this symbol the name «sign — lattice». And he also, supporting the opinion of O. Suleimenov, associates this sign only with the Moon, and then writes that this sign is transformed into the sign of the Sun.

\section{Methods and materials}

The main materials for research is the myths and legends of the Turkic peoples and linguistic data in the Turkic languages. And also materials on children's speech were used. The following methods were applied in the research: comparative, descriptive, comparative historical.

And the main method of the article was the mytholinguistic reading of the circle sign with the point inside. in modern Kazakhstani mythology, this symbol is used to reconstruct images, and to explain the mythological meaning of words. This method was first developed by the mythologist S. Qondybai.

\section{Results and Discussion}

Mythologist and linguist S. Qondybai exploring not all letter signs, but only a sign - a lattice, proves a sign of word formation of a sign - a lattice and another principle - the formation of a myth. "The point and circle are the basis of a single image and the foundation of simple two elements. Also, each figure must have its own name, and the two elements must be two words».

He divides the two original words into 'animal' and 'human' in his work «Hyperborea': The Record of Dream». The first is the animal word - $\mathrm{M}$, for example such words as мө, мү, мі, мө, өм, үм (mо, mu, mi, om, um). Second, it is a human word - HГ (NG), that is, the very first sound that man produces when they born - ng. Crying baby! In Kazakh there are a lot of words where the letter $\mathrm{H} \mathrm{(Ng)} \mathrm{meets.} \mathrm{Ыңырсы,}$ ыңылдау, қаңқылдау, еңкілдеу (to groan, mutter, grumble, roar) also others. The sound $\mathrm{H}(\mathrm{Ng}$ ) gives a special melody. In the meaning of the Noun name, the words of music and sound come from the same protoform. 
S. Qondybai in his records points to the affiliation of NG sound not only to the Kazakh language, but also in famous languages such as, English, for example, gong, single and also in Greek, for example, background (phonetics), tone, all these words have the same origin. "As the scientist says, the most important thing is our NG sound, is one of the very first sounds and plays a major role in word formation».

It describes the sound name of the point and circle signs (Figure 2):

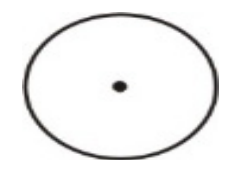

Figure 2. The name of the circle is the sound of $\mathrm{M}$.

The name of the point is the sound of $\mathrm{H}(\mathrm{Ng})$.

By adding vowels to these sounds, new words can be formed. The two elements of this sign may constitute binary opposition to each other. For example, high — low, hot - cold, water - fire, man - woman, mother child and others, as well as it is possible to change the places of these words, circle - water, point - fire, and vice versa, circle - from, point - water and others. Instead of water and fire, you can put in, a man is a woman, a mother is a child, a snake and a tree. On this basis, a new myth is formed if you place each pair in places.

The lattice sign is the basis for the formation of a new myth. Predictors formed new mythical situations by changing the signs of these pairs. S. Qondybai showed seasonal, spatial, qualitative, colored and other parameters of the elements of the lattice sign.

In 2004 published a new study of the mythologist, consisting of 4 books «Mythology of protoKazakhs». In this work he in the process of reconstruction of Kazakh mythology further continued the interpretation of the formation of nature of many world myths, words through the Kazakh language. In his opinion, «myth — is a stereotype of» understanding, «that is, a set of such concepts as, habitat (Time and space) of a society of people who lived a certain historical time, In a definitely geographical space that operated in a definitely political, cultural and agricultural situation, About the universe, how it appeared, about humanity, and how it appeared, About the internal and external forces that influence man, about the place of their society in the universe and about the position.... myth - is not a invented fiction, A lie, an unnatural essence, but the truth of a certain people and its nature» $[4 ; 25]$. He believed that «semantics and etymology are the most important components for mythological reconstruction in the spheres and points» of linguistics, by means of which there is an opportunity to restore and revive myths. In this book, the scientist showed how to separate the accumulation sign from the lattice sign. In the book «Hyperborea: The Record of Dream», the scientist first considers this sign, and describes it as follows: «During the work on this book, the author tells that he only at the beginning of the study of such a reading, «that is, the ways of reading the sign of the lattice has many more stages of research, that he was unable to understand all the ways of reading the sign of the lattice, which is an amazing matrix». Now, I have only moved to the next stage of reading, and I feel that this is not the last stage» $[4 ; 66]$.

The author in the book «Hyperborea...» despite continuing his thought, he changed the sound name of the sign. It takes the sign point of the lattice and the accumulation sign (four, six, eight ray and others) as the point of the $\mathrm{H} / \mathrm{NG}$. Changing the sound $\mathrm{H}$ to other consonant sounds shows in the following example (Figure 3):

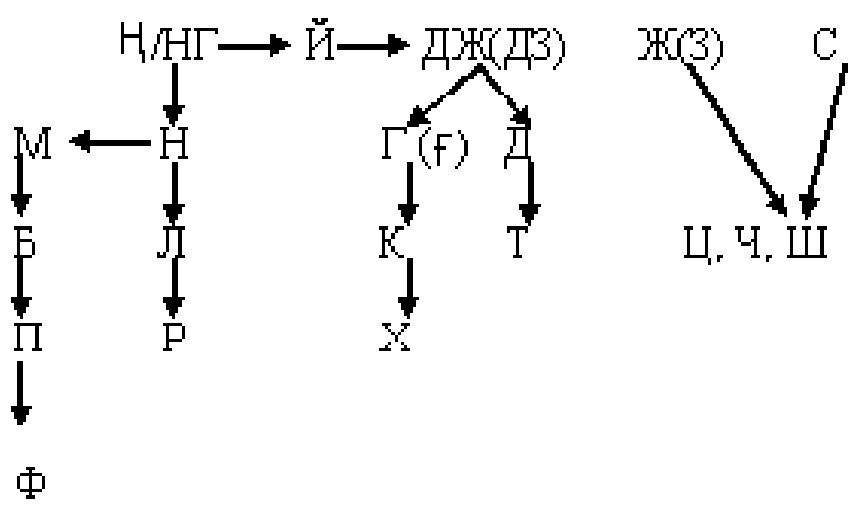

Figure 3. S. Qondybai's example 
Mythologist and linguist shows his examples of sound changes and also he takes into account the fact that he is not a specialist in any certain sounds, however, believes that this example (matrix, transformation) for mythological reconstruction is sufficient.

As we stated above, feature of this book, it — the fact that the sound $\mathrm{y}$ is the name and a point and a circle. In his previous book it was specified that «the name of a circle $-\mathrm{m}$, and the name of a point - $\mathrm{H}$ », but it is possible to notice that it changed (or developed) the opinion. «The sound ng (н) can be the name and points, and a circle. Because a circle is two continuous forms: 1) it can be imagined as an enlarged view of a point; 2) it can give the boundary, shape and parameters of space. It can both increase and shrink... That is, because of the fact that, initially, the protopform ng (н) was «an expanded form» of a circle which had such name of a point became also the name of a circle, corresponding to value of a beam and circle, becomes also the name of a beam: and a point — ng (ң), and a circle — ng (н), and a beam — ng (ң) [4; 72].

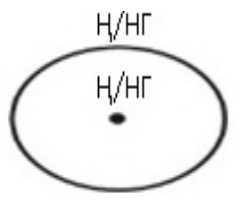

Figure 4. Sign lattice

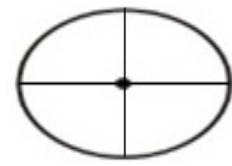

Figure 5. This is one variant of the accumulation sign, it can be six, eight ray etc.
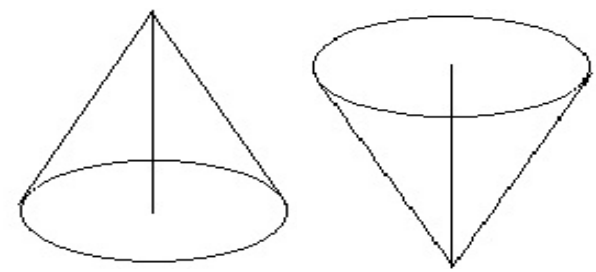

Figure 6. The point can be changed high or low. As the result this, new values of the word (sound) occur.

It is investigative it is possible to take the general name of this sign as - $\mathrm{y}$ or separate forms (figure), it is also possible to call - $\mathrm{H}(\mathrm{ng})$. Despite the fact that the name of the point in the below figures is preserved, new situations and values are formed due to the location(Figure 4, 5). Opposition is born high-low, in consequence, one because of height symbolizes such values as mountain, rock, top, and the second hole, bottom, cave. In order to explain in more detail the idea of the scientist, let us give an example with the word nothing (ew/esh) (Figure 6).

He agrees with the thought of S. Hawking in the book «A Brief History of Time», namely, «Initially, there was nothing. The universe was born of nothing, the whole mass of the universe accumulated at one point». This thought corresponds to one sura from the sacred Quran: «He is the Original of Heaven and Earth... He has created all things and is aware of all things» (Al-Angam 6:101). "What interests me is that the point is defined by the words» nothing, no. The words are Kazakh. Therefore, travelling through the history of word formation, it can be clarified that the concept of the formation of the universe (mythical and real) lies in the word of the Kazakh language» [4; 82].

The word «Ештене» (nothing), consists of two components - еш and еңт. If to show through the sign of a lattice, the name of a circle - ең/енг, the name of a point - еңт/енгт. If «Ең — circle» is a defined boundary, «енг» is something that is beyond that «bounder» (Figure 1 and 6).

On the first picture, is the form «View from the Height» and on the second picture, the form «View from Side». If by the sign, the name of a certain circle and the common sign is - ең, then the name of the center of the point is - Еңт. Еңт is old a Turkic protophorm of a word - еш: еңт> ейт> еджт> ешт> еш. Ең is the name of the universe. Thus, from the word еш, the word ең (universe) came out or in another way, a conclusion is formed - the universe was formed from nothing. The point is a symbol of height, in the texts of the sacred Quran, the full thought lies in this one Kazakh word. A point is the beginning, starting point of 
all, and all or early cause. With the help of a point you can symbolize power, light, glow, center. The basis of all the protophorms is one. For this reason, you can use one instead of the other. Variant ең in Kazakh a word ен which occurs in phrases ең биік, ең бірінші, ен дала, ен жайлау (the highest, very first, spacious steppes, boundless open spaces) and adds such concepts as, «the highest among high», «first among the first», «spacious, boundless». In this case, the point is perceived as, first among the first, the main among the main etc. It is called the word «ең» in the meaning Absolute. Absolute - means «everything is present forever, unchanged basis, and undisputed age. Kazakh words «ең» and «ен» have the meaning of basic, spacious, unlimited, have the sign of point and circle, sign of lattice and have retained their values until now. Originally, it was only the word «yet» and was called so only a sign (and a circle, and a point), and then became the name of two elements (S. Qondybai further considering the protophorms «ең» and «еңт», stops at the difference of these protophorms from each other with the letter $-\mathrm{t}$ ).

\title{
Conclusions
}

It is known that the point inside the circle is a sign in the sound of the NT found in the records of the ancient Turkish language. In the Yenisei inscriptions this symbol, is the sign of a sound $\mathrm{H}$. The point sign inside the circle is multifunctional. As S. Qondybai showed, it has several meanings. O. Suleimenov's opinion on the sign is considered one-sided. Because, the point inside the circle is a symbol not only of the Sun and the Moon, but also of the whole Universe. It can be noticed that the sign can completely describe our environment, habitat and essence. For example, environment or circle - if you take the Mother, her center or point, it is a child. It is known that the first abode of the child in the circle, that is, in the womb, and after he is born, he will live in the circle (earth). In ancient Saki's ancestors, there was a tradition of circling the house when a man dies, which means surrounding a man (drawing a circle) escorted him into the afterworld (perhaps because of this there was a superstition about the prohibition to spin around a man). This applies not only to humans, but also to the animal and plant world. As is known, the lair, the hole, the nest of birds, the web, the ant tree have the shape of a circle, even pets and cattle such as a ram or cow lie, forming a circle. So they all instinctively form a point within the circle. Since humanity is part of nature, it repeats after Mother Nature. According to psychoanalysts, even the drawing of three or four summer children is similar to pictograms on the stones of the Paleolithic. When a child first draws something, they are first inaudibly drawn and then draw spiral circles and paint the middle with a tight dot.

So, the very first sign - the sign of a point in a circle, and its sound name - a sound iңə (inga) which for the first time is published by the human child.

\section{References}

1 Сулейменов О. Язык письма. Взгляд в доисторию - о происхождении письменности и языка малого человечества / О. Сулейменов. - Алматы-Рим, 1998. - С. 497.

2 Генон Р. Символы священной науки / Р. Генон. — М.: Изд-во «Беловодье», 2002. — 496 с.

3 Қондыбай С. Гиперборея: родословие эпохи сновидений / С. Қондыбай [Электронный ресурс]. — Режим доступа: http://otuken.kz/1-3/

4 Қондыбай С. Арғы қазақ мифологиясы. 1 кітап / С. Қондыбай. - Алматы: Дайк-Пресс, 2004. — 510 б.

\author{
Б.Р. Хасенов, Л.А. Нефедова, А.С. Адилова

\section{Шеңбер ішіндегі нүкте таңбасының мифтік-лингвистикалық интерпретациясы}

\begin{abstract}
Мақала қазақ гуманитарлық ғылымында құбылыс болып саналатын С.Қондыбайдың архетиптік таңба және дыбыс жайлы айтқан гипотезаларына арналған. «Қазақ мифологиясының завхозы» С.Қондыбай аз ғана ғұмырында қазақ ғылымына үлкен төңкеріс жасады. Ол бірнеше ғылыми парадигманы тоғыстырып, мифология, лингвистика саласында жаңалықтар ашқан еді. Түркітанушы ғалымдар сөз басындағы архетип дыбысты көне түркі, орта түркі кезеңдеріндегі жазба мәдениетіміздің жәдігерлерінде кездесетін дыбыстар арқылы анықтайды. Және қазіргі түркі тілдерімен, диалектілерімен салыстырып, басым көпшілігі й дыбысын архетип деп есептейді. Кей ғалымдар бұл пікірмен келіспей, дж аффрикатын алғашқы деп санайды. Кейінгі кездегі зерттеушілер ч, ц аффрикаттары - бірі Батыс Ғұн тілдерінде, бірі Шығыс Ғұн тілдерінде аффрикат болды деген пікірді ұстанады. Ал мифолог С.Қондыбай архетип дыбысқа қатысты ойын басқаша арнада дамытты.
\end{abstract}


Ол О.Сүлейменовтің «алғашқы таңба - шеңбер ішінде нүктесі бар таңба», «барлық әліпбилік таңбалар осы таңбадан басталады» деген ойын басшылыққа алды. Сонымен қатар бұл таңбаның тек Күнге ғана қатысты еместігін дәлелдеп, шеңбер ішінде нүктесі бар таңбаның жаңа оқылу үлгісін көрсетті. Таңбаны «абақ» деп атап, оның дыбыстық аталуын ң дыбысымен белгіледі. Таңбаның былайша аталуын адамзат баласы дүниеге келгенде осы дыбысты айтып келетінімен байланыстырды. Яғни, оның ойынша алғашқы дыбыс/сөз - ң. Мақала авторлары С.Қондыбайдың осы идеяларына жан-жақты сипаттама беріп, оның таңба оқудағы өзіндік ерекшелігін көрсетуге тырысқан.

Кілт сөздер: архетиптік дыбыс, таңба, дыбыс, шеңбер, нүкте, жаратылыс, тілдік таңба, Ай, Күн.

\title{
Б.Р. Хасенов, Л.А. Нефедова, А.С. Адилова
}

\section{Мифо-лингвистическая интерпретация символа «круг с точкой»}

\begin{abstract}
Статья посвящена гипотезам С. Қондыбая об архетипическом символе и звуке. «Завхоз казахской мифологии» С. Қондыбай за короткую жизнь сделал большой переворот в казахской науке. Он объединил несколько научных парадигм и сделал открытие в области мифологии и лингвистики. Ученые-тюркологи определяют архетипические звуки в начале слова посредством фонем, которые встречаются в письменных памятниках древнетюркского и среднетюркского периодов. Сравнивая их с современными тюркскими языками, диалектами, многие определяют звук $\check{u}$ архетипом. Некоторые ученые, не согласные с этим мнением, считают, что аффрикат дж является основой всех гласных. В последнее время исследователи придерживаются мнения, что аффрикаты $ч$ и $u$ были архетипами западно-гуннской и восточно-гуннской ветви соответственно. А мифолог С. Қондыбай гипотезу о первом звуке развивал в другом русле. Он руководствовался идеей О. Сулейменова о том, что «первый символ - «круг с точкой», «все алфавитные символы начинаются с этого знака». Вместе с тем, доказывая, что этот символ относится не только к Солнцу, он показал его новое значение. Знак ученый назвал «абак» и обозначил его звуковым нъ/нг. Название символа связывал с тем, что человек, когда появляется на свет, произносит именно этот звук (обычно крик ребенка в русском языке не обозначается никаким звуком или словом, а в тюркских языках это слово - «іңгәлау»). То есть, по его мнению, первый звук (слова) - н/нг. В данной статье авторы попытались дать полную характеристику этих идей и показать оригинальное прочтение символа «круг с точкой» С. Қондыбаем.
\end{abstract}

Ключевые слова: архетипичный звук, знак, круг, точка, сущность, языковой знак, Луна, Солнце.

\section{References}

1 Suleimenov, O. (1998). Yazyk pisma. Vzhliad v doistoriiu - o proishozhdenii pismennosti i yazyka maloho chelovechestva [Language of writing. A look at prehistory - about the origin of writing and the language of small humanity]. Almaty - Roma [in Russian].

2 Genon, R. (2002). Simboly sviashchennoi nauki [Symbols of sacred science]. Moscow: Izdatelstvo «Belovode» [in Russian].

3 Qondybai, S. Hiperboreia: rodoslovie epokhi snovidenii [Hyperborea: writing of dream]. otuken.kz. Retrieved from http://otuken.kz/1-3/_[in Russian].

4 Qondybai, S. (2004). Argy qazaq mifologiasy [Mythology of proto-Kazakh]. (The first book). Almaty: Dayk-Press [in Kazakh]. 